Article

\title{
Green Infrastructure and Ecological Corridors: A Regional Study Concerning Sardinia
}

\author{
Ignazio Cannas ${ }^{(1)}$, Sabrina Lai ${ }^{(\mathbb{B})}$, Federica Leone * and Corrado Zoppi \\ Department of Civil and Environmental Engineering and Architecture, University of Cagliari, Via Marengo 2, \\ 09123 Cagliari, Italy; ignazio.cannas@unica.it (I.C.); sabrinalai@unica.it (S.L.); zoppi@unica.it (C.Z.) \\ * Correspondence: federicaleone@unica.it; Tel.: +39-070-6755-213
}

Received: 19 March 2018; Accepted: 18 April 2018; Published: 20 April 2018

check for updates

\begin{abstract}
We propose a methodological approach to identify a multifunctional green infrastructure (GI) on the basis of four values (conservation value, natural value, recreation value and anthropic heritage) that represent many functions (biodiversity conservation, supply of ecosystem services, recreation, identity building) performed by the landscape. By taking the Italian region of Sardinia as a case study, we argue that the methodology can support the making of landscape plans as understood in the European Landscape Convention. Moreover, we propose and implement a methodology to identify ecological corridors (ECs) connecting Natura 2000 sites (N2Ss), based on the prioritization of functional land patches related to their suitability to ecosystem services delivery, paying particular attention to biodiversity maintenance and enhancement, and taking Sardinia as spatial regional context. The methodology consists of two steps: (i) identifying the most suitable patches to be included in ECs on the basis of their connectivity, that is, on their negative attitude towards contributing to landscape fragmentation; (ii) assessing, through a discrete-choice-model, the suitability of these ECs to be included in a regional GI, starting from the territorial taxonomy based on biodiversity characteristics related to N2Ss, habitat suitability, and recreational and landscape potentials.
\end{abstract}

Keywords: regional green infrastructure; ecological corridors; ecosystem services

\section{Introduction}

The European Commission [1] (p. 3), in its Communication "Green Infrastructure: Enhancing Europe's Natural Capital”, defines Green Infrastructure (GI) as " (... ) a strategically planned network of natural and semi-natural areas with other environmental features designed and managed to deliver a wide range of ecosystem services." This definition of GI integrates three concepts: ecological connectivity, biodiversity conservation and multifunctionality of ecosystems (of which the last is of particular importance for the spatial identification of a GI within planning tools in compliance with article no. 10 of the Habitats Directive [2]). As a consequence, multifunctionality and connectivity play a key role in the spatial identification of a GI. Indeed, on the one hand, the multifunctional use of natural capital allows to deal with significant issues such as biodiversity conservation and production of ecosystem services (ESs) [3], and on the other hand, the definition of ecological connections among habitats could entail positive effects on habitat fragmentation [4].

An important set of ecosystem services (ESs) delivered by GIs is based on habitats and species protection and enhancement, that is on maintaining and improving biodiversity's conservation status. This is in accordance with the second objective of the EU Biodiversity Strategy, which recommends that ecosystems and their services be maintained and enhanced by establishing GIs and restoring at least a $15 \%$ of the ecosystems which show significant decay. From this perspective, habitat fragmentation can be considered one the most outstanding causes of a decreasing attitude of GIs towards the delivery 
of habitat-based ESs, since it weakens the capacity to deliver such services by undermining the networking potential of habitats.

We implement an approach which, following McHarg's cultural and scientific vision [5] aims to identify a multifunctional GI on the basis of four values (conservation value (C_Val), natural value (N_Val), recreation value (R_Val) and anthropic heritage (A-Her)) that represent as many functions (biodiversity conservation, supply of ecosystem services, recreation, cultural heritage) performed by the landscape. C_Val expresses the landscape capacity of preserving biodiversity since it accounts for rare or threatened habitats. N_Val accounts for a landscape's potential to supply ecosystem services under the assumption that the better the quality of biodiversity, the greater its capability of providing such services. R_Val considers landscape as a determinant of people's preferences concerning the use of their leisure time. A_Her, in compliance with the European Landscape Convention, accounts for the interactions between natural capital and human factors that have shaped cultural identities within the European Union. Multifunctionality in relation to GI is conceived as the capacity of a single area to perform several functions and/or to provide various benefits [6]; it aims at integrating several functions (environmental, social, cultural, economic, etc.) and, thus, at enabling a more efficient use of space [7]. In fact, without appropriate management, competition for the use of a given land parcel could entail potential conflicts [8]. Some authors [9] maintain that the use of the concept of multifunctionality in relation to GI is a stratagem in order not to choose among competing functions, based on the assumption that a GI can simultaneously provide several functions [6,10]. However, some functions can actually conflict with each other and, as a consequence, it is difficult for them to work simultaneously [9]. Therefore, potential conflicts between functions cannot be effectively addressed only through appropriate management, because they can possibly cause negative impacts on biodiversity conservation [4].

Connectivity can be defined as the degree to which the landscape affects species movement [11] in a fragmented context [12]. In the literature, connectivity is regarded either as a physical phenomenon (structural connectivity) or in terms of functional connectivity of species. In particular, the latter is related to species' behavior in response to landscape structure and to the landscape structure per se as well [13]. Although analyses based on structural connectivity are less complicated, for example in terms of input data requirements [14], functional connectivity recognizes the species-specific character of connectivity [15]. So far, only some attempts have been made to combine functional and structural connectivity [16]. However, mapping and assessing functional connectivity is a complex task because of the scarcity of data available to implement species-specific assessments and because results depend on methods to analyze preferences in terms of species movements [15].

Therefore, spatial identification of a GI represents an unresolved issue for spatial planning at various scale levels. In our view, integrating GI into planning policies is likely to support decision-making processes related to environmental conservation and protection; at the same time, it is likely to promote the integration of biodiversity conservation within planning policies as stated by article no. 10 of Council Directive 92/43/EEC "on the conservation of natural habitats and of wild fauna and flora" (Habitats Directive), implemented into the Italian legislation by article no. 2 of the Presidential Decree n. 1997/357. As per article no. 10 of the Habitats Directive, the Natura 2000 Network has to be ecologically and functionally connected by ecological corridors (ECs), that is, areal elements that connect habitats to support biodiversity conservation and enhancement, and, by doing so, increase in the supply of ESs [17]. Thus, the spatial identification of ECs is an important foundation of protection and long-term conservation of biodiversity functions on the basis of prioritization of spatial elements [18] that show low resistance to species movements.

In this study, we aim at developing a methodological tool to support planners in identifying GIs starting from functions that landscapes are likely to support and perform. On this basis, we propose a methodological approach to identify a regional GI, taking Sardinia (Italy) as a case study. In particular, we aim at: (i) defining a taxonomy to evaluate the suitability of landscape patches to be included in a regional GI in relation to four values (conservation value, natural value, recreational value and 
anthropic heritage); (ii) identifying the most suitable patches to be included in ECs on the basis of their connectivity, that is, on their negative attitude towards contributing to landscape fragmentation; and, (iii) assessing, through a discrete-choice-model, the suitability of the identified ECs to be included in a regional GI, based on the taxonomy defined above.

This article is structured into four sections. The second section presents the Sardinian case study and explains the methodology we use to identify a regional GI. The third section reports the results of our analysis. In the concluding section we propose a discussion on the implications of the outcomes of our study, policy recommendations and directions for future research.

\section{Materials and Methods}

Sardinian is one of the two largest Italian islands (Figure 1), with a population of around 1.6 million [19]. Its Regional Landscape Plan (RLP), approved in 2006, does not provide explicit rules for identifying a GI; however, articles nos. 23 and 26 of the plan implementation code provide restrictions to maintain ecological functions and article no. 34 promotes the integration of Natura 2000 sites (N2Ss) within a coherent ecological network. In fact, Sardinia is characterized by a significant Natura 2000 Network that covers approximately 19\% of the regional area and concerns 37 Sites of Community Importance (SCIs), 56 Special Areas of Conservation (SACs), and 37 Special Protection Areas (SPAs) [20].

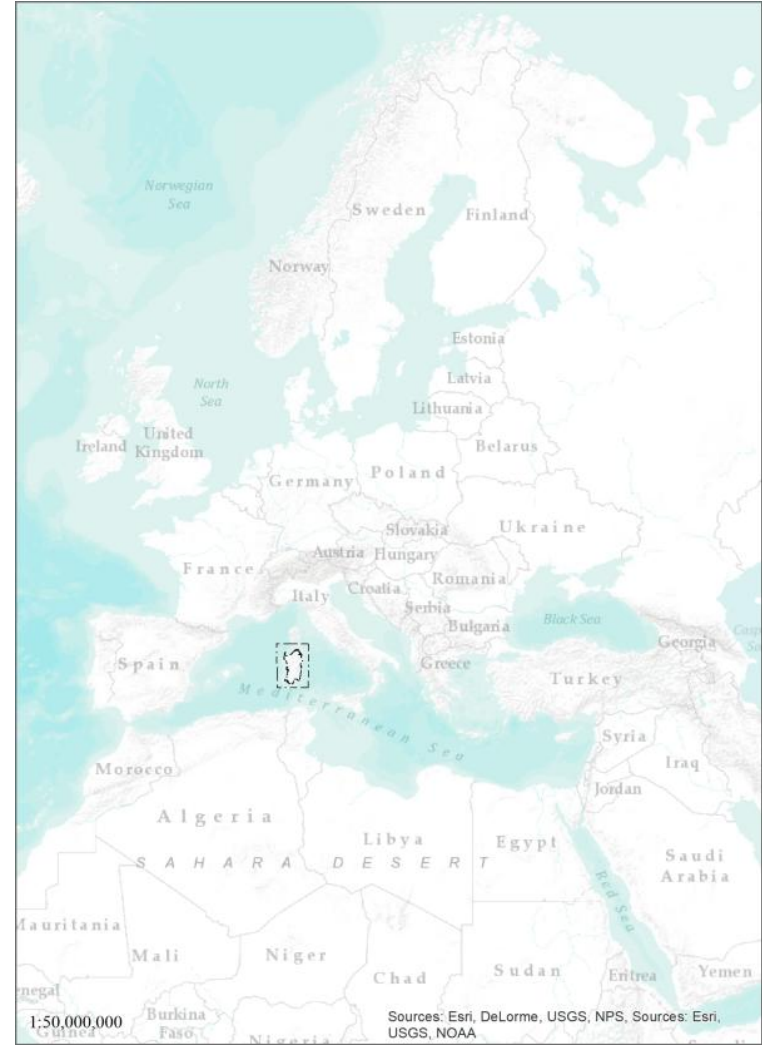

(a)

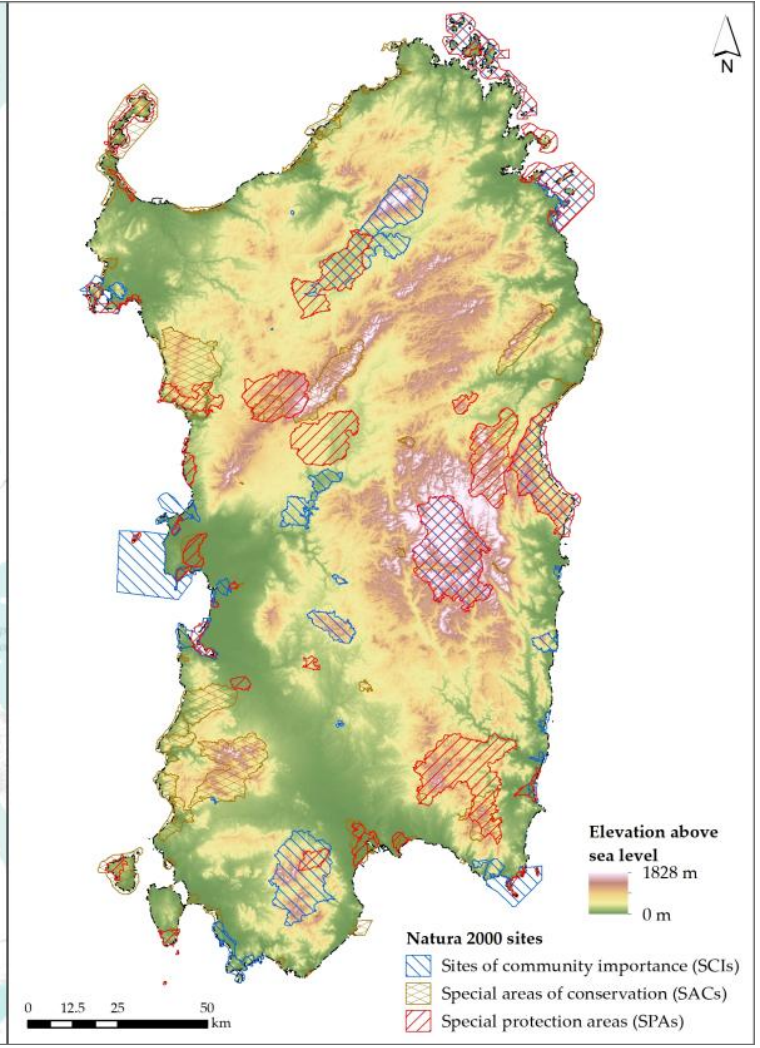

(b)

Figure 1. (a) Location of Sardinia within the Mediterranean Sea; (b) The Sardinian Natura 2000 Network.

These features make Sardinia suitable to our research study which aims at assessing the suitability of landscape patches and ECs to be included into a regional GI. Our methodological approach is discussed in the three following subsections. In the first section, we define a taxonomy to assess how, and to what extent, regional land parcels are suitable to be included into a regional GI. Secondly, we discuss how to identify parcels that are suitable to be considered part of ECs on the basis of their 
connectivity, whose size is related to the negative contribution to landscape fragmentation. In the third subsection, we assess the suitability of ECs to be included into a regional GI, identified through a spatial classification based on the taxonomy defined in the first subsection.

\subsection{Definition of a Taxonomy to Identify a Regional GI}

Building upon Arcidiacono et al. [21], we identify a multifunctional GI in relation to four elements: conservation value, natural value, recreational value and anthropic heritage. Each of the four values is calculated through a specific procedure and all values are mapped through the software ArcGIS ${ }^{\circledR}$ ESRI.

The conservation value (C_Val) looks at the presence of habitats defined by article no. 1 of the Habitats Directive as "natural habitat types of community interest" and listed in Annex I of the same Directive. C_Val is calculated through a procedure that builds upon a recent regional report [22] (pp. 27-28), where habitats of community interest are categorized in order to elaborate a regional monitoring plan of Sardinia. In particular, C_Val equals zero in those areas that do not host any habitats of community interest; otherwise it is calculated according to the following formula:

$$
C_{-} \text {Val }=\mathrm{P} \times(\mathrm{R}+\mathrm{T}+\mathrm{K}),
$$

where $P$ accounts for priority, which equals 1.5 in the case of priority habitats [23] and 1 otherwise (Table A1 in Appendix A). $R$ indicates the habitat rarity and it is calculated in relation to the number of Sardinian N2Ss in which the habitat is present (Table A1 in Appendix A); higher values of $R$ correspond to lower number of occurrences. $T$ evaluates the number of threats recorded in the Standard Data Forms of the Sardinian N2Ss [24] (Table A2 in Appendix A); in this case higher values of $T$ correspond to higher number of occurrences. K accounts for knowledge and it is based on a recent regional monitoring project where the level of knowledge is evaluated qualitatively through experts' judgments [25] (Table A1 in Appendix A). Apart from $K$, whose values were ranked in the interval (1-4), all values were normalized in the interval (1-5). C_Val can initially take values ranging from 0 (areas where no habitats of community interest are present) to 21 (maximum conservation value), and it is next normalized in the interval (0-1).

The natural value (N_Val) goes beyond the intrinsic conservation value of biodiversity and assesses the quality of biodiversity in relation to three aspects: ecological integrity, actual levels of ecosystems functions, and capacity to provide ESs despite pressures and threats that may affect habitats. N_Val is assessed through the tool "Habitat quality" of the software "InVEST" that maps habitat quality in relation to land covers and threats to biodiversity [26]. In particular, input data for the model are as follows:

1. the 2008 Land Cover Map elaborated by the Sardinian regional administration converted into a raster map;

2. a list of 10 threats identified through an analysis of Standard Data Forms of the Sardinian N2Ss; for each threat we assign a weight and decay distance, assessed on the basis of experts' judgments and a decay function (Table 1); to this end, five experts (with backgrounds in natural sciences, biology, agricultural sciences, and geology) in biodiversity, environmental impact assessment and appropriate assessment under the Habitats directive were delivered a questionnaire;

3. a raster map representing the spatial layout of each threat;

4. a vector map that shows accessibility to sources of degradation, conceived as protection that legal institutions provide against threats, where the higher the level of protection, the lower the value of accessibility. We identify three levels of protection: regional and national parks (value $=0.2$ ); N2Ss (value $=0.5)$; the remaining study area $($ value $=1)$;

5. a matrix of habitat types starting from land covers, and, for each habitat type, its sensitivity to each threat. Values are identified through an expert-based approach [27] (Table A3 in Appendix A); and,

6. a "half-saturation constant", set at the tool's default value. 
Table 1. List of threats to biodiversity in the Sardinian Region and related weights, decay distances and decay functions.

\begin{tabular}{ccccc}
\hline Threat Code & Threat Name & Weight & Decay Distance $\mathbf{( k m )}$ & Decay Function \\
\hline T01 & Cultivation & 0.58 & 1.63 & linear \\
T02 & Grazing & 0.68 & 0.58 & linear \\
T03 & Removal of forest undergrowth & 0.79 & 0.65 & linear \\
T04 & Salt works & 0.63 & 0.83 & linear \\
T05 & Paths, tracks & 0.53 & 0.55 & linear \\
T06 & Roads, motorways & 0.95 & 3.00 & linear \\
T07 & Airports & 0.95 & 4.75 & linear \\
T08 & Urbanized areas & 0.95 & 3.25 & linear \\
T09 & Discharges & 1.00 & 3.50 & linear \\
T10 & Fire & 0.95 & 2.05 & linear \\
\hline
\end{tabular}

The recreational value (R_Val) concerns the quantitative assessment of an ES, categorized by the Millennium Ecosystem Assessment [28] under the "cultural services" group, and accounts for landscape and natural habitats as key factors that influence people's behavior in relation to their leisure time. Recreational services can be assessed through monetary [29] or non-monetary evaluations [30]. In particular, non-monetary analyses include approaches based on social media, such as Flickr [31] and Instagram [32], that estimate visitors' preferences in relation to the number of their uploaded geotagged pictures. In our study, R_Val is calculated and mapped through the tool "Visitation: Recreation and Tourism" [33] of the software InVEST that uses data from the social media Flickr; the unit of measure is the "photo-user-day" (PUD) that corresponds to the number of users that took at least one photo in a given spatial unit and day. Data are retrieved within the 2010-2014 timeframe, and the average PUD per year was normalized in the interval (0-1).

The anthropic heritage (A_Her) indicator accounts for interactions between natural capital and human factors in relation to the definition of landscape provided by the European Landscape Convention, according to which landscape includes all those elements that have contributed to define cultural identities within the European Union. In Italy, landscapes are interpreted, protected, managed and planned through specific plans, defined under the provisions of the Convention, called "Landscape plans", whose structure and implementation varies depending on the regional contexts. A_Her concerns the protection level that the Sardinian Regional landscape plan (RLP) defines for each landscape asset; a value between 0 and 1 is assigned depending on the strictness of the rules defined by the RLP (the more rigid the rules, the higher the value) [34] (Table A4 in Appendix A).

Finally, in order to obtain the total value, the two raster maps concerning N_Val and R_Val are converted into vector maps, and next a GIS geoprocessing tool calculates the total value as the sum of the four values (C_Val, N_Val, R_Val and A_Her). Since the four values range between 0 and 1 , the total value ranges in the interval (0-4).

\subsection{Identification of Ecological Corridors through Connectivity}

ECs aim at maximizing the availability of ESs while supporting species movements. Recently, promising research works have been implemented with reference to "Least-cost path" algorithms (LCPs), which are effective in identifying planning scenarios which entail ECs and in prioritizing patches connecting N2Ss [2,35-40]. For this reason, we use LCPs- and cost weighted distance-based analyses (CWDs). As Adriaensen et al. [35] show, LCPs identification needs two inputs: a source layer representing patches for which the model calculates the connectivity, and a friction/resistance layer based on two types of information for each cell of a spatial grid: a resistance value and its spatial position and orientation. The resistance value defines the cost of species movements based on the land cover associated to each patch. Species movements are influenced by: (i) the energy consumption implied by the movement; (ii) the mortality risk; and, (iii) the negative effect on future reproductive potential. These characteristics are represented by the value of cost-resistance associated to each 
patch. Through the LCPs we identify paths featured by the least effort or the lowest cost, in terms of species movement. We use all the Sardinian N2Ss as a source layer to be connected and we derive the resistance layer from the data available in the literature on the basis of the concept of habitat suitability. Thus, the identification of ECs is structured in three phases as follows.

First, we draw a habitat suitability map (Figure A1a in Appendix A) by taking into account that the patches located outside the boundaries of the N2Ss can be regarded as habitats as well as patches located inside. The habitat suitability value represents the probability of a habitat being used by a particular species [41,42]. Generally, habitat suitability indexes are defined through expert opinions [40,43]. In our study, we identify global values of habitat suitability on the basis of a report, concerning the environmental status of the N2Ss, commissioned by the Sardinian regional administration to AGRISTUDIO et al. [44]. A global value of habitat suitability is assigned to each land cover class of the Corine Land Cover (CLC) [45] identified inside and outside the N2Ss of the Sardinian region. This value is the result of the weighted mean of the values of the habitat suitability associated to each CLC class in relation to all species cited in the above-mentioned report (104 species are listed). The CLC classes are related to the linear and areal elements of the land cover map of Sardinia.

Second, we draw a resistance map representing the spatial distribution of the cost-resistances concerning the movements of species related to the physical characteristics of the environmental context. Resistance values are computed by inverting the values of habitat suitability $[37,38,43,46]$. Our resistance map takes account of areal and linear elements. Indeed, after mapping the resistance of the areal elements, we increase the resistance values by summing the values of the street network, and we decrease them on the basis of the hydrological network; it is worth mentioning, though, that for few species hydrological networks can work as barriers.

Third, we scale the values of the resistance map in the (1-100) interval, where 100 represents the highest resistance and 1 the lowest [37]. The resulting map (Figure A1b in Appendix A) shows the spatial layout of cost-resistance to the movements of species in relation to the landscape and environmental contexts due to the land cover types.

Finally, we identify the ECs through the GIS tool Linkage Mapper [47]. This tool implements connectivity analysis by using the resistance map and the map of the core areas, namely, the N2Ss, on the basis of the identification of the least-cost paths. ECs are identified by means of targeted adjacent core areas and of the network of the least-cost paths based on connectivity analysis implemented through CWDs and LCPs.

\subsection{Suitability of Ecological Corridors to Be Included into a Regional Green Infrastructure}

We implement a dichotomous choice model (DCM) in order to analyze the suitability of parcels belonging to ECs to be included into the GI identified according to the taxonomy, whose methodology for defining is explained in the first section with reference to the Sardinian region. DCMs assess processes featured by ordinal variables, related to mutually exclusive alternatives. The pioneering studies of McFadden [48,49] are reference points for the theoretical foundations as regards behavioral models regarding the choices of agents. Williams' work [50] is generalized by McFadden [48,49,51] who implements agent-choice models related to standardized microeconomics by integrating heterogeneous characteristics of agents, which may not necessarily be part of the information available to the modeler; in case they are not, they would be included in the model as random features. DCMs can be implemented with reference to stylized studies available in the literature [52-54] which imply the assumptions of incomplete information and imperfect rationality of the agents [55]. Furthermore, in our model we take as granted that the random utility functions of the agents are not correlated with each other. In this study, we use a Logit DCM (LM) to evaluate the suitability of a land patch, which is located in an EC as per the methodological approach proposed in the Section 2.2, to be included into the regional GI as per the taxonomy whose methodology for defining is explained in the Section 2.1. We implement our LM following Zoppi and Lai's [56], Nerlove and Press' [57] and Greene's [58] (pp. 666-672). We use the following variables: 
- a binary variable (ECGI), concerning land patches, which equals 1 if a patch, located in an EC, is included into the regional GI as per the taxonomy, whose methodology for defining is explained in the Section 2.1, or 0 otherwise; and,

- three explanatory variables (C_Val, N_Val, R_Val) concerning the values of conservation, nature and recreation, that is the features of a land patch which are taken into consideration to decide over its inclusion in the regional GI. Descriptive statistics are shown in Table 2.

Table 2. Descriptive statistics.

\begin{tabular}{ccc}
\hline Variable & Mean & St. Dev. \\
\hline ECGI & 0.541 & 0.498 \\
C_Val & 0.156 & 0.205 \\
N_Val & 0.811 & 0.260 \\
R_Val & 0.006 & 0.032 \\
\hline
\end{tabular}

\section{Results}

3.1. Definition of a Taxonomy to Identify the Regional GI

Figure 2 displays the spatial layout of the four values in our case-study area.

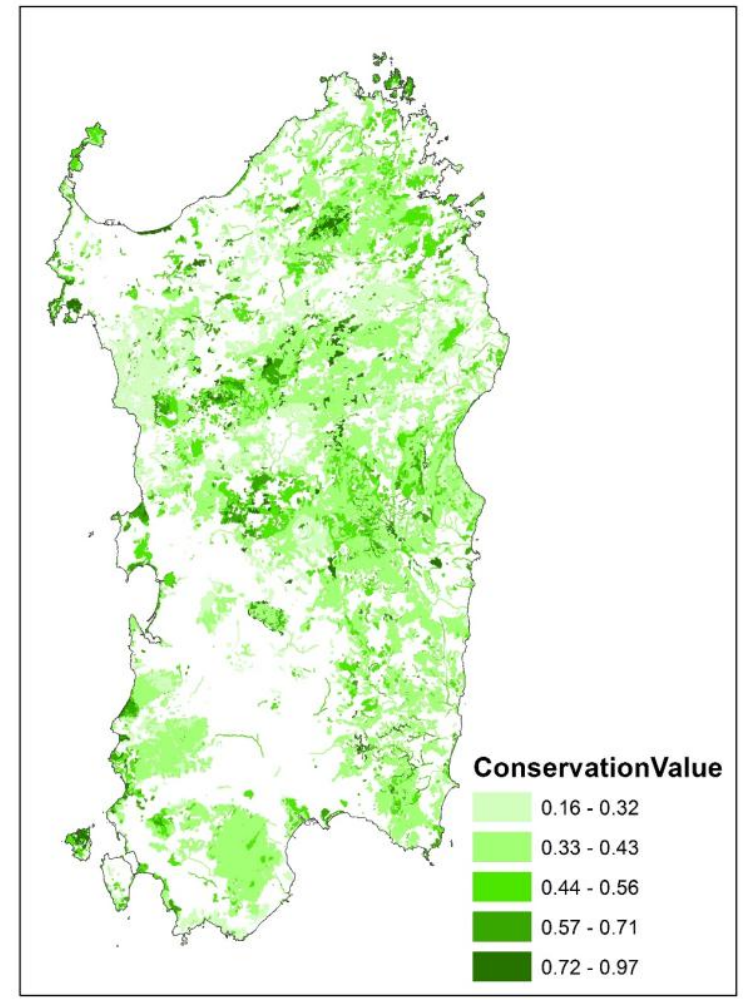

(a)

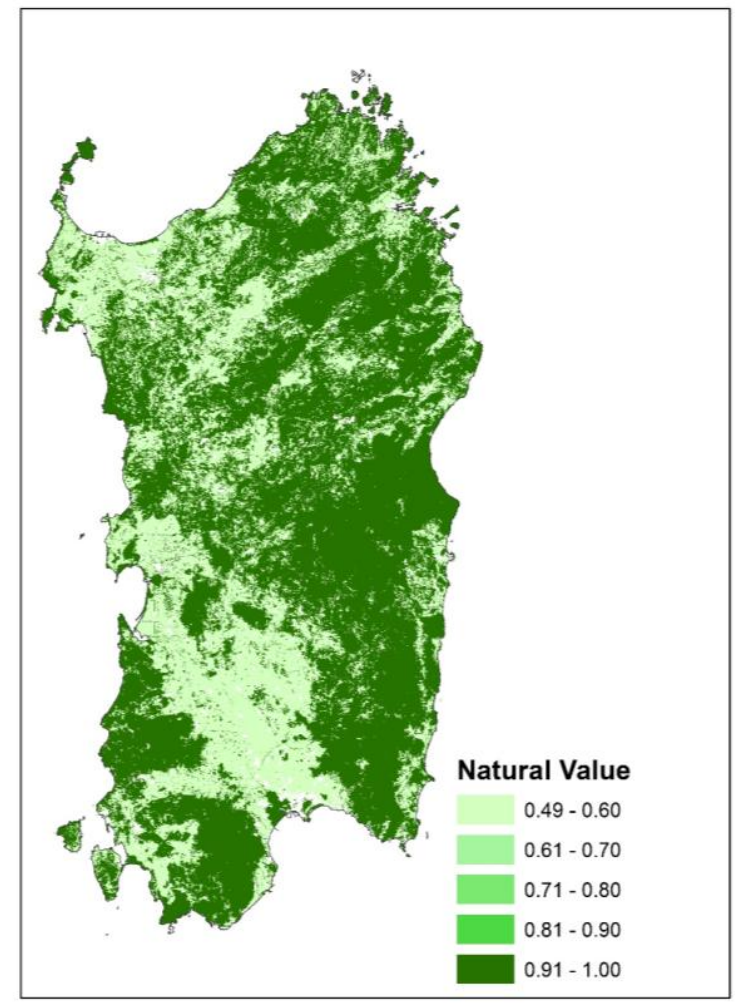

(b)

Figure 2. Cont. 


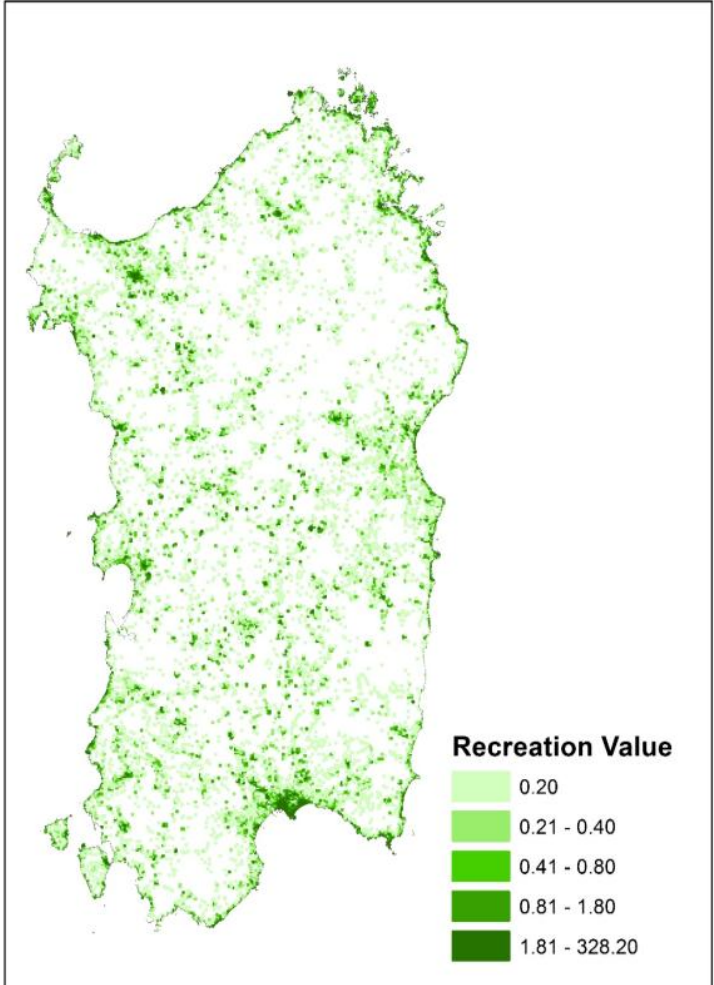

(c)

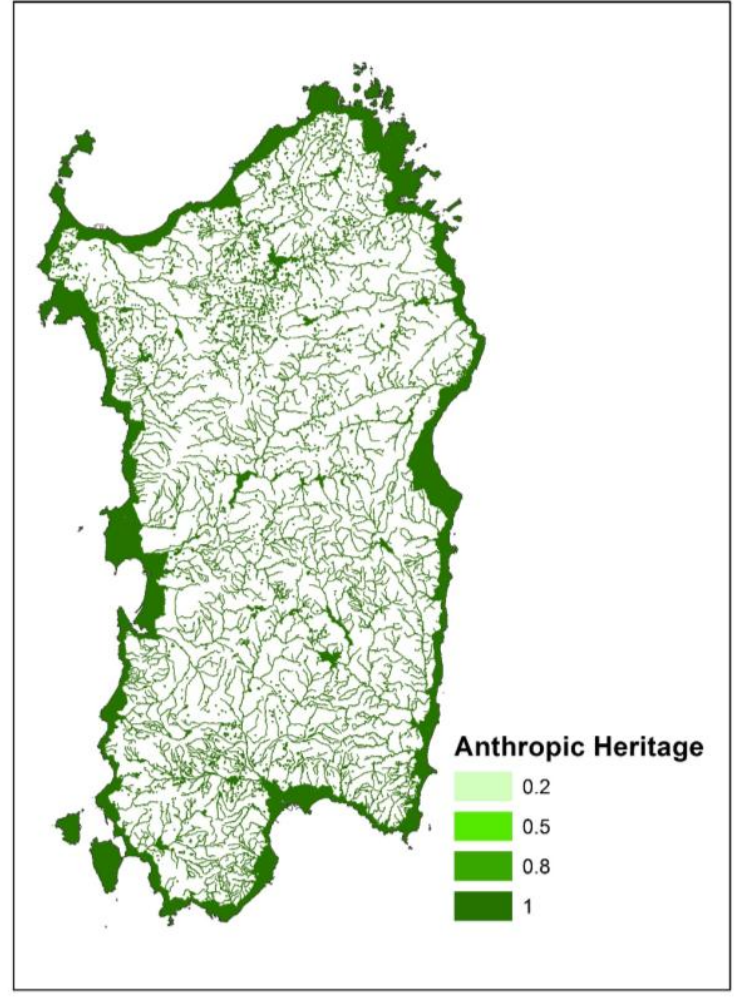

(d)

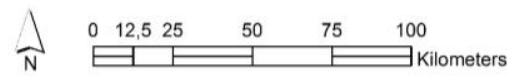

Figure 2. Spatial distribution of conservation value (a); natural value (b); recreational value (c) and anthropic heritage (d) in the Sardinian case study.

A large part of the island (approximately 66\%) takes null C_Val, which means that it does not host any habitats of community interest. Out of the rest of the island (34\%), in which such habitats can be found, the most part takes low values: only $0.90 \%$ of the island's surface takes values higher than $0.75 ; 4.95 \%$ takes values between 0.50 and 0.75 , and finally $27.80 \%$ shows values below 0.50 . Moreover, since the regional Natura 2000 Network covers around 19\% of the region [20], it follows that a good deal of habitats of community interest are not included within any N2Ss.

As for N_Val, only a small part of the island (3.26\%) takes null values; $34.29 \%$ of the region hosts middle-quality habitats taking values around 0.50 , while $62.45 \%$ corresponds to high quality habitats taking values above 0.90 .

R_Val equals 0 in the vast majority of the island (84.86\%). Out of the remaining $15.14 \%, 13.43 \%$ of the island's land area takes values between 0.01 and 0.10 , hence only a very small part of the island (mostly in the main towns and along the coastline) takes middle or high values.

Finally, A_Her equals 0 in $61.18 \%$ of the region. Furthermore, this variable is categorical and only takes the following values: 0.20 (0.26\% of the regional land mass); $0.5(4.21 \%) ; 0.8(4.17 \%)$ and 1 $(30.18 \%)$. Therefore, among non-null values, the maximum value spatially dominates, mainly because of three main environmental assets ("Coastal strip", "Lakes, reservoirs, wetlands and their 300-m buffers" and "(listed) Rivers, creeks and their 150-m buffers"). A fourth type of asset also brings about the maximum value, and comprises both "Listed archaeological heritage" and "Areas with prehistoric, historic, cultural remnants".

The total value map (Figure 3) shows that in no point is the maximum possible score (i.e., 4) achieved. This also implies that no land parcel simultaneously achieves the maximum score in each of the four values. Null total values only concern $0.76 \%$ of the region, while the highest value 
(corresponding to 3.53) concerns a negligible area of 1.5 hectares. The highest values are associated either with coastal areas (and especially within coastal wetlands) or with the summit of hills and mountains; rivers and creeks also stand out, as they always show total values higher than those of their surrounding landscapes.

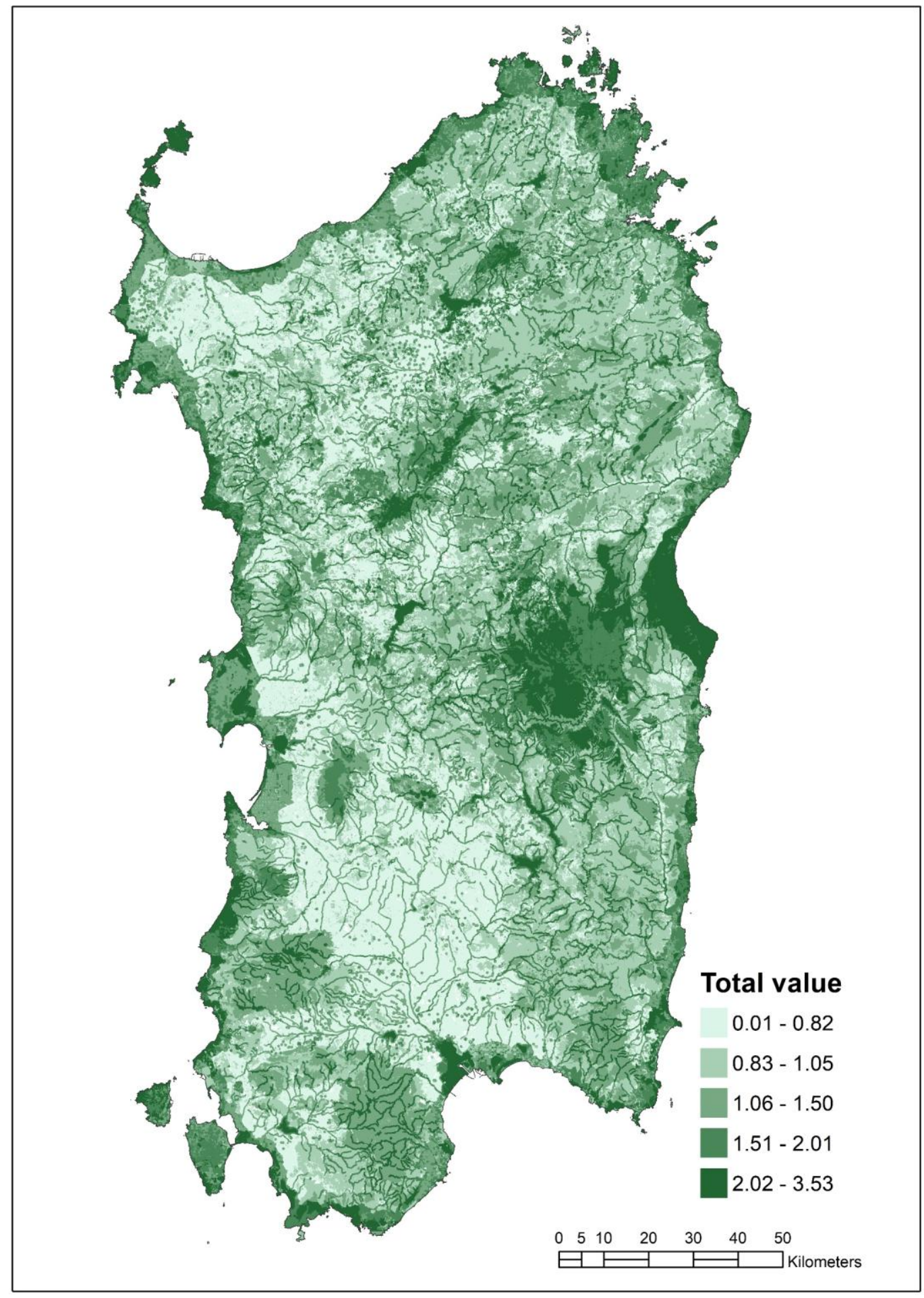

Figure 3. Spatial distribution of total landscape value in the Sardinian case study. 


\subsection{Identification of Ecological Corridors}

The ECs identification, implemented through Linkage Mapper, generates two outcomes. First, a composite raster map which represents ECs identified by the resistance map and the use of LCPs and CWDs. This raster map contains values ranging from 0 to 656,074 kilometers. Second, a linear shape file containing the normalized least-cost corridors (170 links are identified). McRae and Kavanagh [59] suggest using the variable computed by the ratio of CWDs to the Euclidean distances as a qualitative metric of the ECs. This entails that high values correspond to high movement costs along the path of least resistance, and low values indicate high quality in terms of connectivity. Since the ECs, i.e., the least-cost corridors, are defined as linear elements, we reclass the raster map of normalized corridors (CWD values are shown in Figure 4a) in ten deciles, in order to identify two-dimensional ECs, rather than only linear elements. All the patches whose values are included in the first set are assumed to be part of the ECs. Around 2\% of the Sardinian regional area belongs to the first set. The identified ECs are mainly agricultural areas $(21.6 \%)$ and forest and semi-natural areas $(77.6 \%)$.

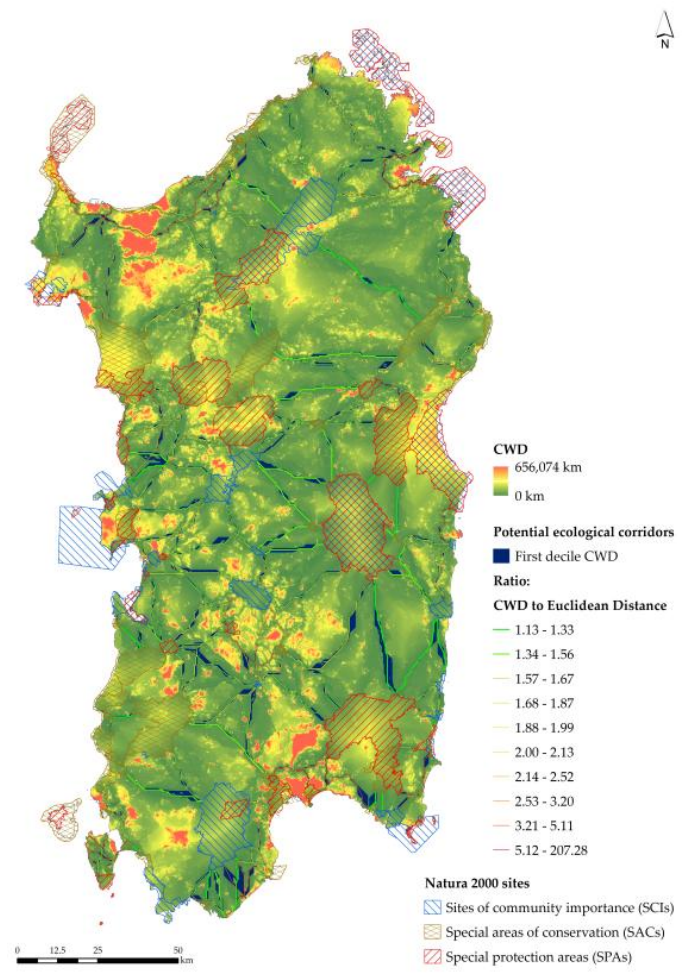

(a)

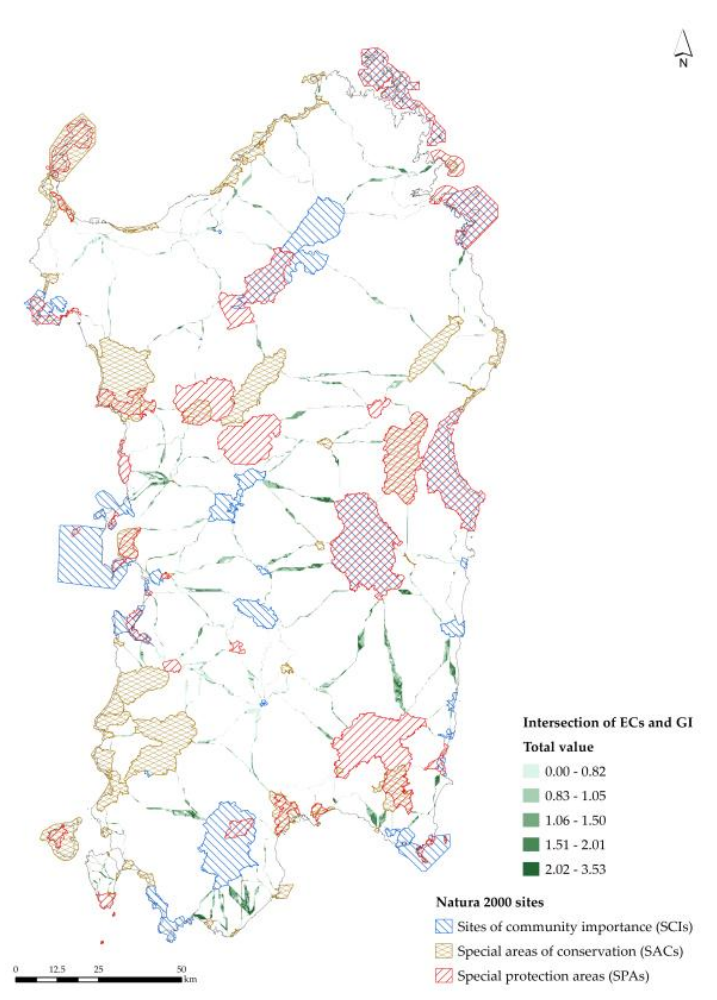

(b)

Figure 4. (a) Ecological corridors (ECs) in Sardinia; (b) Intersection of ECs and the regional Green Infrastructure (GI).

\subsection{Suitability of Parcels Located in ECs to Be Included into the Regional GI}

The intersection of the maps of ECs and of the regional GI (Figure 4b) returns 9513 land patches. We estimate the probability of each patch to be part of the regional GI, namely, the probability that $Y$ equals 1.

Table 3 reports the marginal effects of independent variables on the probability of a patch to be included in the regional GI entailed by the results of the LM. As regards the goodness of fit statistics, our outcomes show that the probability values of the $Y=1$ event are not significantly different from the estimated values, either in terms of the log-likelihood test or with reference to the Hosmer and Lemeshow's [60] test. 
Table 3. Marginal effects on the probabilities of $Y=1$ of the variables related to conservation, natural and recreational values.

\begin{tabular}{|c|c|c|c|}
\hline Variable & Marginal Effect & Z-Statistic & $\begin{array}{l}\text { Hypothesis Test: } \\
\text { Marginal Effect }=0\end{array}$ \\
\hline \multicolumn{4}{|c|}{ Marginal impact on $Y=1$ probability, $\mathrm{dProb}(\mathrm{Y}=1) / \mathrm{dx}$, Prob $(\mathrm{Y}=1)=0.541$} \\
\hline C_Val & 0.258 & 9.814 & 0.0000 \\
\hline N_Val & 0.181 & 8.817 & 0.0000 \\
\hline R_Val & 3.351 & 8.062 & 0.0000 \\
\hline \multicolumn{4}{|c|}{$\begin{array}{l}\text { Log-likelihood goodness-of-fit test. } \\
\text { Log-likelihood ratio }=6393.446-\text { Prob. }>\text { chi-square }=0.00000 \text { ( } 3 \text { degrees of freedom }) \text {. } \\
\text { Hosmer and Lemeshow [60] goodness-of-fit test. } \\
\text { HL }=646.10767-\text { Prob. }>\text { chi-square }=0.00000 \text { ( } 8 \text { degrees of freedom })\end{array}$} \\
\hline
\end{tabular}

Furthermore, the size and sign of the estimated coefficients are consistent with expectations. Conservation value (C_Val in Tables 2 and 3) is related to two determinants, which influence the probability that a patch belongs to the regional GI: (i) habitats of community interest; and, (ii) threats, level of knowledge on the habitats status and rarity.

As regards the presence of habitats, a ten percent increase of C_Val at the mean value implies a $2.6 \%$ increase in the probability that a patch belongs to the regional GI. Furthermore, if a patch and a priority habitat overlap, this entails that the probability is $54 \%$ higher than in the case they do not overlap (see Table 3). With reference to the second factor, higher levels of threats, uncertainty on the habitats status, and rarity are connected to higher levels of probability. The ESs supply provided by biodiversity, which defines the value of nature (N_Val in Tables 2 and 3) is positively correlated to the probability of a land patch belonging to an EC to be included in the regional GI. This is consistent with expectations since the patches included in ECs are comparatively more adequate to house species protected under the provisions of the Habitats Directive, and to supply biodiversity-related ESs. For instance, our outcomes indicate that if $\mathrm{N}_{-} \mathrm{Val}$ increases by $10 \%$ at the mean value, the probability that a patch belongs to the regional GI increases by $1.8 \%$. According to our outcomes, Recreation value ( $\mathrm{R}_{-} \mathrm{Val}$ in Tables 2 and 3), which is based on the users' (local visitors and tourists) revealed interest towards sites, concerning historic and archaeological heritage and natural attractiveness of a given location of the Sardinian region, has the highest marginal impact on the probability of a patch to be included into the regional GI among the three explanatory variables of the DCM LM, since a $10 \%$ increase in R_Val implies a 33.5\% increase in the probability that a patch belongs to the regional GI, which is more than ten times the marginal effect of $C_{-}$Val and nearly twenty times the marginal effect of N_Val. Finally, even though the value of recreation is hard to handle in terms of definition and implementation of planning policies; however, our outcomes indicate that the attractiveness of valuable environmental contexts definitely matters in decision-making processes related to environment and protection of nature and natural resources.

\section{Conclusions}

In this study we propose a methodology to support the spatial identification of a multifunctional regional GI, based on three steps. The first concerns the definition of a taxonomy whereby landscape patches suitable to be included into a regional GI are identified by singling out four main functions (conservation of endangered or otherwise valuable habitats, biodiversity support, recreation, interactions between people and landscapes) that a GI should support and ensure. For each function, a quantitative index was proposed, assessed and mapped. In the second step, we identify the most suitable land parcels to be included in ECs on the basis of their connectivity, which consists in their negative attitude towards contributing to landscape fragmentation. In the third step, we assess, by means of a DCM LM, the ECs identified in the second step in terms of their suitability to be 
included in a multifunctional regional GI, founded on the spatial classification related to biodiversity characteristics concerning N2Ss, that is, on the values of conservation, nature and recreation.

In relation to the first step, a first, not surprising, outcome of the study is that the four values vary differently across space; this was to be expected, because each value captures a specific aspect or function relevant to landscape planning. For instance, within urban and rural settlements $C_{-}$Val is null and N_Val tends to be null as well; to the contrary, within built-up areas R_Val can take high values, as well as A_Her in the case of historic districts or listed buildings and monuments can be found inside the settlements. This is consistent with the view that multifunctionality is an ideal objective [61] when designing a GI, because each land parcel is somewhat "specialized", meaning that it performs at least one main function, and different parcels complement each other. Consequently, a first recommendation to planners and policy makers is that tradeoffs between areas performing different functions need to be preliminarily brought to the fore in planning processes that concern the spatial identification and management of GI.

A second striking outcome is that that no land parcel achieves the maximum possible total score, which equals 4 . This is related to the previous comment, and it is due to the fact that no land parcel simultaneously achieves the maximum score in each of the four values here considered, because a single land parcel is unlikely to perform all of the functions at the highest level. The highest values (3.51-3.53) in our case study characterize some parts of a wetland and former saltwork within the built-up area of Cagliari, where N_Val, R_Val and A_Her take the maximum value while C_Val scores approximately 0.5 . This is certainly a peculiar situation, in which habitats of community interest (C_Val) and in comparatively favorable status notwithstanding threats and pressures (N_Val) are protected by the landscape plan (A_Her) because of their being included in the coastal strip and because of the conservative regime that applies to coastal wetlands, while being at the same time easily accessible and enjoyed (R_Val) by local communities and visitors. Hence, a second recommendation is that natural and semi-natural habitats, be they of community interest or not, that survive and thrive within, or in proximity to, urban areas should be granted a special protection regime which should not turn them into strict nature reserves or wilderness areas (respectively, categories I.a and I.b of the IUCN protected area management category scheme). Controlled access to these habitats is, actually, important not only because it enables visitors to spend time in contact with nature, but also because such habitats and their landscapes are, in the words of the European Landscape Convention [62], "an essential component of people's surroundings ( ... ) and a foundation of their identity".

A third outcome concerns the spatial distribution of C_Val. By superimposing the spatial layout of the regional Natura 2000 Network upon the maps representing C_Val, it is quite easy to notice that quite a large area hosting habitats of community interest is not included within any N2Ss. While the presence of a habitat or species of community interest does not automatically call for the designation of a N2S (in particular, for SCIs and SACs, criteria listed in Annex III of the Habitats Directive apply), effective protection policies should be envisaged in relevant planning tools so as to maintain these habitats or species. The RLP currently in force in Sardinia does provide both regulations and planning directions aiming at preserving specific habitats of community interest listed in the Habitats Directive, and especially priority habitats: for instance, article no. 17 of its planning implementation code includes Posidonia beds (priority habitat ${ }^{*} 1120$ ) and steppic habitats (priority habitat ${ }^{*} 6220$ ), as well as any priority habitat listed in the Directive, among landscape assets, which are subject to several restrictions; article no. 23 forbids any non-conservative forestry interventions in any priority habitats; article no. 39 forbids land cover changes and transformations in areas outside the Natura 2000 Network hosting habitats listed in the Directive if the habitat's structure and function can be adversely affected. However, all of these provisions are not effective because such areas are not mapped in the plan's maps, which are legally binding, hence restrictions cannot be enforced.

A fourth remark concerns the map presented in Figure 3, which should not be conceived as the spatial configuration of a Sardinian GI, but rather as a tool to help policy makers choose which possible areas could be included in a GI within a regional and normative spatial plan. 
In this study we have attempted to address the current "limited success" [63] in institutionalizing GI: our view is that, if the identification of GI, as well as the provisions for its management, were mandatorily included within landscape plans, then GI could effectively be institutionalized. As per legislative decree $42 / 2004$, Italian regional administrations have the duty to prepare and approve landscape plans; in these plan-making processes, participation is compulsory and is integrated within the strategic environmental assessment procedure pursuant to European Directive 2001/42/EC. A key aspect of such participatory processes is their capability of including ESs beneficiaries' [64] knowledge, needs, and priorities in the plan-making process. This kind of participation could possibly enhance the methodology we have proposed in this study, because it could allow for the integration of ESs beneficiaries' views and priorities in regard to the four constituent values, which we assessed and mapped here on the basis of official data and expert views only.

In relation to the second and third step, our study shows (Table 3) that, even though ECs are identified as part of GIs as per the European Commission [1], nevertheless in the case of Sardinia just a $54 \%$ share of the identified ECs belongs to the regional GI, which is an issue that calls for great attention. The nodes of the Natura 2000 Network consist of SAC, SPA and SCI, whose connections are represented by ECs. The characteristics of parcels included into the ECs are related to habitats of community interest located either outside or inside the N2Ss. In the absence of restrictive rules related to the Birds and Habitats Directives, habitats of community interest can possibly suffer from negative impacts generated by anthropic activities such as new productive and residential developments. Suitable planning measures should be identified in order to protect the local contexts from land-taking processes caused by urbanization policies. These measures should be implemented on the basis of solid scientific and technical foundations and expertise. Indeed, our outcomes show that the Sardinian public administrations (the Region and municipalities) should press the national government and the European Union to extend the conservation approach defined under the provisions of the Birds and Habitats Directives to areas outside N2Ss, in order to spread protection measures as much as possible over the rest of the regional land.

Moreover, our study shows that ESs supplied by biodiversity are very important, with particular reference to N_Val. Indeed, N_Val is positively correlated to the probability of a land patch belonging to an EC to be included in the regional GI, and, as previously mentioned, at the mean value, a $10 \%$ increase in N_Val by $10 \%$ generates a $1.8 \%$ increase in the probability that a patch belongs to the regional GI. This is a fundamental issue in order to promote the integration of ECs into the regional GI. Local, regional and national bodies should improve and support conservation of areas featured by significant ECs supply potentials, by using: (i) solid scientific and technical knowledge concerning interdisciplinary fields related to relationships between ESs and land cover typologies; (ii) mitigationand prevention-related measures regarding land take, with reference to on-going and future anthropic developments; and, (iii) policies which aim at protecting and enhancing the ESs provision.

Furthermore, our results show an important effect of the value of recreation on the probability of a patch to be part of the regional GI. Actually, its marginal impact exceeds by $130 \%$ the value of conservation. It has to be put in evidence that the value of an area in terms of its attractiveness related to leisure is rather volatile and needs more analysis and research than the available studies can provide right now. As a consequence, future research should also address this issue.

In terms of directions for future development of this research, we highlight the following items. First, participatory processes whereby ESs beneficiaries' expectations and priorities are embedded in the methodology should be included, so as to enhance the methodology itself.

Secondly, since maintaining or enhancing the ESs productive potential is likely to produce negative effects in terms of impacts on other ESs, by weakening the forcefulness of measures stated to grant their conservation. For example, enhancing and catalyzing leisure- and recreation-related ESs (the cultural-service category of the classification of the Millennium Ecosystem Assessment [28]), or improving agricultural output (the provisioning service category of the classification of the Millennium Ecosystem Assessment) is likely to cause negative effects on species and habitats located 
either in the N2Ss or elsewhere, and, that being so, they are likely to decrease their capacity of producing supporting services (a further category of the Millennium Ecosystem Assessment). As a consequence, we believe that a promising future research direction implied by our study is the appraisal and assessment regarding possible trade-offs between the improvement/worsening of production potentials of different categories of ESs due to the conservation policies implemented to protect N2Ss. Several scholars address this trade-off issue. For example, Kovács et al. [65], among many, analyze non-monetary trade-offs related to three Hungarian protected sites.

Last but not least, our methodology and its implementation can be exported and experimented with in other regional contexts of the European Union, where N2Ss are established so as to implement ECs into the nodes of the Natura 2000 Network, which are presently disconnected, and, by doing so, to make it consistent with the provisions of the Habitats Directive.

Acknowledgments: This study was supported by the Research Program "Natura 2000: Assessment of management plans and definition of ecological corridors as a complex network," funded by the Autonomous Region of Sardinia for the period 2015-2018, under the Call for "Projects related to fundamental or basic research" of the year 2013, implemented at the Department of Civil and Environmental Engineering and Architecture (DICAAR) of the University of Cagliari, Italy.

Author Contributions: Ignazio Cannas, Sabrina Lai, Federica Leone and Corrado Zoppi collaboratively designed the concept of this research study, the proposed methodology and its implementation. Individual contributions are as follows: Sabrina Lai defined the content of Section 1, of the introductory part of Section 2, and of Section 2.1; Ignazio Cannas has taken care of Sections 2.2 and 3.2; Corrado Zoppi wrote Sections 2.3 and 3.3; and, Federica Leone has taken care of Section 3.1 and of Section 4.

Conflicts of Interest: The authors declare no conflict of interest. The founding sponsors had no role in the design of the study; in the collection, analyses, or interpretation of data; in the writing of the manuscript, and in the decision to publish the results.

\section{Appendix A}

Table A1. List of natural habitat types of community interest (coded according to the Habitats Directive), indication whether the habitat is a "priority habitat" (on which P is based: no = 1; yes = 1.5), number of standard data forms in which they are listed in Sardinian N2Ss (upon which R is calculated as normalized value in the 1-5 interval), knowledge levels (on which $\mathrm{K}$ is assessed: good = 1; sufficient = 2; insufficient $=3$; poor $=4$ ) as assessed by [22].

\begin{tabular}{|c|c|c|c|c|}
\hline $\begin{array}{l}\text { Habitat } \\
\text { Code }\end{array}$ & Habitat Denomination & $\begin{array}{l}\text { No. of Standard } \\
\text { Data Forms }\end{array}$ & $\begin{array}{l}\text { Priority } \\
\text { Habitat }\end{array}$ & $\begin{array}{l}\text { Knowledge (at the } \\
\text { Regional Level, } \\
\text { Year 2014) }\end{array}$ \\
\hline 1110 & $\begin{array}{l}\text { Sandbanks which are slightly covered by sea } \\
\text { water all the time }\end{array}$ & 42 & No & Poor \\
\hline 1120 & Posidonia beds (Posidonion oceanicae) & 67 & Yes & Sufficient \\
\hline 1130 & Estuaries & 3 & No & Poor \\
\hline 1150 & Coastal lagoons & 48 & Yes & Insufficient \\
\hline 1160 & Large shallow inlets and bays & 36 & No & Sufficient \\
\hline 1170 & Reefs & 39 & No & Poor \\
\hline 1210 & Annual vegetation of drift lines & 57 & No & Insufficient \\
\hline 1240 & $\begin{array}{l}\text { Vegetated sea cliffs of the Mediterranean coasts } \\
\text { with endemic Limonium spp. }\end{array}$ & 53 & No & Good \\
\hline 1310 & $\begin{array}{l}\text { Salicornia and other annuals colonising mud } \\
\text { and sand }\end{array}$ & 27 & No & Sufficient \\
\hline 1410 & Mediterranean salt meadows (Juncetalia maritimi) & 52 & No & Sufficient \\
\hline 1420 & $\begin{array}{l}\text { Mediterranean and thermo-Atlantic halophilous } \\
\text { scrubs (Sarcocornetea fruticosi) }\end{array}$ & 53 & No & Good \\
\hline 1430 & Halo-nitrophilous scrubs (Pegano-Salsoletea) & 12 & No & Poor \\
\hline 1510 & Mediterranean salt steppes (Limonietalia) & 39 & Yes & Insufficient \\
\hline
\end{tabular}


Table A1. Cont.

\begin{tabular}{|c|c|c|c|c|}
\hline $\begin{array}{l}\text { Habitat } \\
\text { Code }\end{array}$ & Habitat Denomination & $\begin{array}{l}\text { No. of Standard } \\
\text { Data Forms }\end{array}$ & $\begin{array}{l}\text { Priority } \\
\text { Habitat }\end{array}$ & $\begin{array}{l}\text { Knowledge (at the } \\
\text { Regional Level, } \\
\text { Year 2014) }\end{array}$ \\
\hline 2110 & Embryonic shifting dunes & 46 & No & Insufficient \\
\hline 2120 & $\begin{array}{l}\text { Shifting dunes along the shoreline with } \\
\text { Ammophila arenaria (white dunes) }\end{array}$ & 41 & No & Sufficient \\
\hline 2210 & Crucianellion maritimae fixed beach dunes & 47 & No & Sufficient \\
\hline 2230 & Malcolmietalia dune grasslands & 41 & No & Insufficient \\
\hline 2240 & Brachypodietalia dune grasslands with annuals & 24 & No & Poor \\
\hline 2250 & Coastal dunes with Juniperus spp. & 41 & Yes & Sufficient \\
\hline 2260 & Cisto-Lavenduletalia dune sclerophyllous scrubs & 9 & No & Poor \\
\hline 2270 & $\begin{array}{l}\text { Wooded dunes with Pinus pinea and/or } \\
\text { Pinus pinaster }\end{array}$ & 24 & Yes & Sufficient \\
\hline 3120 & $\begin{array}{l}\text { Oligotrophic waters containing very few } \\
\text { minerals generally on sandy soils of the West } \\
\text { Mediterranean with Isoetes spp. }\end{array}$ & 6 & No & Poor \\
\hline 3130 & $\begin{array}{l}\text { Oligotrophic to mesotrophic standing waters } \\
\text { with vegetation of the Littorelletea uniflorae } \\
\text { and/or IsoetoNanojuncetea }\end{array}$ & 16 & No & Insufficient \\
\hline 3150 & $\begin{array}{l}\text { Natural eutrophic lakes with Magnopotamion- or } \\
\text { Hydrocharition-type vegetation }\end{array}$ & 6 & No & Poor \\
\hline 3170 & Mediterranean temporary ponds & 18 & Yes & Poor \\
\hline 3280 & $\begin{array}{l}\text { Constantly flowing Mediterranean rivers with } \\
\text { Paspalo-Agrostidion species and hanging curtains } \\
\text { of Salix and Populus alba }\end{array}$ & 8 & No & Poor \\
\hline 3290 & $\begin{array}{l}\text { Intermittently flowing Mediterranean rivers of } \\
\text { the Paspalo-Agrostidion }\end{array}$ & 5 & No & Poor \\
\hline 4090 & Endemic oro-Mediterranean heaths with gorse & 3 & No & Sufficient \\
\hline 5210 & Arborescent matorral with Juniperus spp. & 53 & No & Good \\
\hline 5230 & Arborescent matorral with Laurus nobilis & 10 & Yes & Insufficient \\
\hline 5320 & Low formations of Euphorbia close to cliffs & 25 & No & Insufficient \\
\hline 5330 & Thermo-Mediterranean and pre-desert scrub & 79 & No & Insufficient \\
\hline 5410 & $\begin{array}{l}\text { West Mediterranean clifftop phryganas } \\
\text { (Astragalo-Plantaginetum subulatae) }\end{array}$ & 8 & No & Poor \\
\hline 5430 & Endemic phryganas of the Euphorbio-Verbascion & 37 & No & Insufficient \\
\hline 6210 & $\begin{array}{l}\text { Semi-natural dry grasslands and scrubland facies } \\
\text { on calcareous substrates(Festuco-Brometalia) } \\
\text { (important orchid sites) }\end{array}$ & 3 & Yes & Poor \\
\hline 6220 & $\begin{array}{l}\text { Pseudo-steppe with grasses and annuals of the } \\
\text { Thero-Brachypodietea }\end{array}$ & 68 & Yes & Insufficient \\
\hline 6310 & Dehesas with evergreen Quercus spp. & 18 & No & Sufficient \\
\hline 6420 & $\begin{array}{l}\text { Mediterranean tall humid herb grasslands of the } \\
\text { Molinio-Holoschoenion }\end{array}$ & 4 & No & Poor \\
\hline 7220 & $\begin{array}{l}\text { Petrifying springs with tufa formation } \\
\text { (Cratoneurion) }\end{array}$ & 1 & Yes & Poor \\
\hline 8130 & Western Mediterranean and thermophilous scree & 1 & No & Poor \\
\hline 8210 & $\begin{array}{l}\text { Calcareous rocky slopes with } \\
\text { chasmophytic vegetation }\end{array}$ & 11 & No & Insufficient \\
\hline 8220 & $\begin{array}{l}\text { Siliceous rocky slopes with } \\
\text { chasmophytic vegetation }\end{array}$ & 4 & No & Insufficient \\
\hline 8310 & Caves not open to the public & 17 & No & Sufficient \\
\hline 8330 & Submerged or partially submerged sea caves & 15 & No & Insufficient \\
\hline 91E0 & $\begin{array}{l}\text { Fluvial forests with Alnus glutinosa and Fraxinus } \\
\text { excelsior (Alno-Padion, Alnion incanae, } \\
\text { Salicion albae) }\end{array}$ & 16 & Yes & Insufficient \\
\hline 9260 & Castanea sativa wood & 1 & No & Insufficient \\
\hline
\end{tabular}


Table A1. Cont.

\begin{tabular}{|c|c|c|c|c|}
\hline $\begin{array}{l}\text { Habitat } \\
\text { Code }\end{array}$ & Habitat Denomination & $\begin{array}{l}\text { No. of Standard } \\
\text { Data Forms }\end{array}$ & $\begin{array}{l}\text { Priority } \\
\text { Habitat }\end{array}$ & $\begin{array}{l}\text { Knowledge (at the } \\
\text { Regional Level, } \\
\text { Year 2014) }\end{array}$ \\
\hline $92 \mathrm{~A} 0$ & Salix alba and Populus alba galleries & 13 & No & Sufficient \\
\hline 92D0 & $\begin{array}{l}\text { Southern riparian galleries and thickets } \\
\text { (NerioTamaricetea and Securinegion tinctoriae) }\end{array}$ & 51 & No & Insufficient \\
\hline 9320 & Olea and Ceratonia forests & 41 & No & Sufficient \\
\hline 9330 & Quercus suber forests & 22 & No & Sufficient \\
\hline 9340 & Quercus ilex and Quercus rotundifolia forests & 52 & No & Insufficient \\
\hline 9380 & Forests of Ilex aquifolium & 6 & No & Sufficient \\
\hline 9540 & $\begin{array}{l}\text { Mediterranean pine forests with endemic } \\
\text { Mesogean pines }\end{array}$ & 8 & No & Poor \\
\hline 9560 & Endemic forests with Juniperus spp. & 1 & Yes & Poor \\
\hline 9580 & Mediterranean Taxus baccata woods & 9 & Yes & Sufficient \\
\hline
\end{tabular}

Table A2. List of Sardinian N2Ss for which at least one negative threat is listed in their 2016 standard data forms, and no. of negative threats (upon which $\mathrm{T}$ is calculated, as normalized value in the 1-5 interval).

\begin{tabular}{|c|c|c|c|c|c|}
\hline Site Code & No. of Negative Threats & Site Code & No. of Negative Threats & Site Code & No. of Negative Threats \\
\hline ITB010001 & 5 & ITB023049 & 2 & ITB041106 & 9 \\
\hline ITB010002 & 8 & ITB023050 & 6 & ITB041111 & 4 \\
\hline ITB010003 & 23 & ITB030032 & 20 & ITB041112 & 6 \\
\hline ITB010004 & 9 & ITB030034 & 11 & ITB042207 & 3 \\
\hline ITB010006 & 3 & ITB030035 & 11 & ITB042208 & 1 \\
\hline ITB010007 & 9 & ITB030036 & 6 & ITB042209 & 2 \\
\hline ITB010008 & 14 & ITB030037 & 8 & ITB042210 & 1 \\
\hline ITB010009 & 3 & ITB030038 & 14 & ITB042216 & 15 \\
\hline ITB010011 & 26 & ITB031104 & 16 & ITB042218 & 4 \\
\hline ITB010042 & 8 & ITB032219 & 20 & ITB042220 & 12 \\
\hline ITB010043 & 6 & ITB032228 & 17 & ITB042223 & 9 \\
\hline ITB010082 & 8 & ITB032229 & 15 & ITB042225 & 2 \\
\hline ITB011102 & 9 & ITB032239 & 3 & ITB042226 & 4 \\
\hline ITB011109 & 11 & ITB032240 & 3 & ITB042230 & 10 \\
\hline ITB011155 & 21 & ITB034004 & 2 & ITB042231 & 3 \\
\hline ITB012211 & 4 & ITB034006 & 6 & ITB042233 & 1 \\
\hline ITB012212 & 2 & ITB034007 & 5 & ITB042234 & 10 \\
\hline ITB012213 & 1 & ITB040017 & 10 & ITB042236 & 6 \\
\hline ITB013011 & 1 & ITB040018 & 16 & ITB042237 & 6 \\
\hline ITB013012 & 8 & ITB040019 & 7 & ITB042241 & 4 \\
\hline ITB013018 & 3 & ITB040020 & 22 & ITB042242 & 2 \\
\hline ITB013019 & 11 & ITB040021 & 12 & ITB042243 & 3 \\
\hline ITB013044 & 22 & ITB040022 & 12 & ITB042247 & 10 \\
\hline ITB020012 & 9 & ITB040023 & 9 & ITB042250 & 5 \\
\hline ITB020013 & 11 & ITB040024 & 7 & ITB042251 & 2 \\
\hline ITB020014 & 9 & ITB040025 & 16 & ITB043025 & 4 \\
\hline ITB020015 & 5 & ITB040026 & 3 & ITB043026 & 3 \\
\hline ITB020040 & 18 & ITB040027 & 19 & ITB043027 & 3 \\
\hline ITB021101 & 6 & ITB040028 & 6 & ITB043028 & 4 \\
\hline ITB021103 & 8 & ITB040029 & 21 & ITB043032 & 15 \\
\hline ITB021107 & 2 & ITB040031 & 3 & ITB043035 & 7 \\
\hline ITB021156 & 8 & ITB040051 & 7 & ITB043054 & 10 \\
\hline ITB022212 & 13 & ITB040071 & 19 & ITB043055 & 15 \\
\hline ITB022214 & 18 & ITB040081 & 3 & ITB044002 & 7 \\
\hline ITB022215 & 4 & ITB041105 & 10 & ІTВ044009 & 7 \\
\hline
\end{tabular}


Table A3. Input data for N_Val: matrix of habitat scores (0: not habitat; 0.5: potential habitat; 1: habitat) starting from land covers; for each habitat type, a sensitivity score is assigned to each threat listed in Table 1.

\begin{tabular}{|c|c|c|c|c|c|c|c|c|c|c|c|}
\hline $\begin{array}{c}\text { Landcover } \\
\text { Type }\end{array}$ & $\begin{array}{l}\text { Habitat } \\
\text { Scores }\end{array}$ & $\begin{array}{c}\text { Sens_ } \\
\text { T01 }\end{array}$ & $\begin{array}{c}\text { Sens_ } \\
\text { T02 }\end{array}$ & $\begin{array}{c}\text { Sens } \\
\text { T03 }\end{array}$ & $\begin{array}{c}\text { Sens_ } \\
\text { T04 }\end{array}$ & $\begin{array}{c}\text { Sens_ } \\
\text { T05 }\end{array}$ & $\begin{array}{c}\text { Sens_ } \\
\text { T06 }\end{array}$ & $\begin{array}{c}\text { Sens_ } \\
\text { T07 }\end{array}$ & $\begin{array}{c}\text { Sens_ } \\
\text { T08 }\end{array}$ & $\begin{array}{c}\text { Sens_ } \\
\text { T09 }\end{array}$ & $\begin{array}{r}\text { Sens } \\
\text { T10 }\end{array}$ \\
\hline 111 & 0 & 0 & 0 & 0 & 0 & 0 & 0 & 0 & 0 & 0 & 0 \\
\hline 112 & 0 & 0 & 0 & 0 & 0 & 0 & 0 & 0 & 0 & 0 & 0 \\
\hline 121 & 0 & 0 & 0 & 0 & 0 & 0 & 0 & 0 & 0 & 0 & 0 \\
\hline 122 & 0 & 0 & 0 & 0 & 0 & 0 & 0 & 0 & 0 & 0 & 0 \\
\hline 123 & 0 & 0 & 0 & 0 & 0 & 0 & 0 & 0 & 0 & 0 & 0 \\
\hline 124 & 0 & 0 & 0 & 0 & 0 & 0 & 0 & 0 & 0 & 0 & 0 \\
\hline 131 & 0 & 0 & 0 & 0 & 0 & 0 & 0 & 0 & 0 & 0 & 0 \\
\hline 132 & 0 & 0 & 0 & 0 & 0 & 0 & 0 & 0 & 0 & 0 & 0 \\
\hline 133 & 0 & 0 & 0 & 0 & 0 & 0 & 0 & 0 & 0 & 0 & 0 \\
\hline 141 & 1 & 0 & 0 & 0 & 0 & 0 & 0.5 & 0.2 & 0.5 & 1 & 1 \\
\hline 142 & 0 & 0 & 0 & 0 & 0 & 0 & 0 & 0 & 0 & 0 & 0 \\
\hline 143 & 0 & 0 & 0 & 0 & 0 & 0 & 0 & 0 & 0 & 0 & 0 \\
\hline 211 & 0.5 & 0 & 0.5 & 0 & 0 & 0 & 0.5 & 0 & 0.5 & 0.5 & 0.5 \\
\hline 212 & 0.5 & 0 & 0.5 & 0 & 0 & 0 & 0.5 & 0 & 0.5 & 0.5 & 0.5 \\
\hline 221 & 0.5 & 0 & 0.5 & 0 & 0 & 0 & 0.5 & 0 & 0.5 & 0.5 & 0.5 \\
\hline 222 & 0.5 & 0 & 0.5 & 0 & 0 & 0 & 0.5 & 0 & 0.5 & 0.5 & 0.5 \\
\hline 223 & 0.5 & 0 & 0.5 & 0 & 0 & 0 & 0.5 & 0 & 0.5 & 0.5 & 0.5 \\
\hline 224 & 1 & 1 & 1 & 0.5 & 0 & 1 & 1 & 0.5 & 1 & 1 & 1 \\
\hline 231 & 1 & 1 & 0.5 & 0 & 0 & 0.5 & 1 & 0.2 & 0.5 & 1 & 1 \\
\hline 241 & 0.5 & 0 & 0.5 & 0 & 0 & 0 & 0.5 & 0 & 0.5 & 0.5 & 0.5 \\
\hline 242 & 0.5 & 0 & 0.5 & 0 & 0 & 0 & 0.5 & 0 & 0.5 & 0.5 & 0.5 \\
\hline 243 & 1 & 0.5 & 1 & 0.5 & 0 & 1 & 1 & 0.2 & 1 & 1 & 1 \\
\hline 244 & 1 & 0.5 & 0.5 & 1 & 0 & 1 & 1 & 0.2 & 1 & 1 & 1 \\
\hline 311 & 1 & 1 & 0.5 & 1 & 0 & 1 & 1 & 0.2 & 0.5 & 1 & 1 \\
\hline 312 & 1 & 1 & 0.5 & 1 & 0 & 1 & 1 & 0.2 & 0.5 & 1 & 1 \\
\hline 313 & 1 & 1 & 0.5 & 1 & 0 & 1 & 1 & 0.2 & 0.5 & 1 & 1 \\
\hline 321 & 1 & 1 & 1 & 0 & 0 & 1 & 1 & 0.5 & 0.5 & 1 & 1 \\
\hline 322 & 1 & 1 & 1 & 0 & 0 & 1 & 1 & 0.5 & 1 & 1 & 1 \\
\hline 323 & 1 & 1 & 1 & 0.5 & 0 & 1 & 1 & 0.5 & 1 & 1 & 1 \\
\hline 324 & 1 & 1 & 1 & 0.5 & 0 & 1 & 1 & 0.5 & 1 & 1 & 1 \\
\hline 331 & 1 & 0 & 0 & 0 & 0 & 1 & 1 & 0.5 & 1 & 1 & 0 \\
\hline 332 & 1 & 0 & 0 & 0 & 0 & 1 & 1 & 0.2 & 1 & 1 & 0 \\
\hline 333 & 1 & 1 & 1 & 0 & 0 & 1 & 1 & 0.5 & 1 & 1 & 1 \\
\hline 411 & 1 & 1 & 0 & 0 & 1 & 0.5 & 1 & 0.5 & 1 & 1 & 0 \\
\hline 421 & 1 & 0.5 & 0 & 0 & 1 & 0.5 & 1 & 0.5 & 1 & 1 & 0 \\
\hline 422 & 1 & 0.5 & 0 & 0 & 0 & 0 & 1 & 0.2 & 1 & 1 & 0 \\
\hline 423 & 1 & 0.5 & 0 & 0 & 0 & 0.5 & 1 & 0.2 & 1 & 1 & 0 \\
\hline 511 & 1 & 0.5 & 0 & 0 & 0 & 0.5 & 1 & 0.2 & 1 & 1 & 0 \\
\hline 512 & 1 & 0.5 & 0 & 0 & 0 & 0.5 & 1 & 0.2 & 1 & 1 & 0 \\
\hline 521 & 1 & 0.5 & 0 & 0 & 1 & 0.5 & 1 & 0.2 & 1 & 1 & 0 \\
\hline 523 & 0 & 0 & 0 & 0 & 0 & 0 & 0 & 0 & 0 & 0 & 0 \\
\hline
\end{tabular}

Table A4. A_Her: types of landscape protection levels established in Sardinia by the RLP, and value assigned on the basis of the restrictions in force.

\begin{tabular}{llcc}
\hline \multicolumn{1}{c}{ Type } & $\begin{array}{c}\text { Plan Implementation } \\
\text { Code: Articles }\end{array}$ & A_Her \\
\hline & Coastal strip & $8,17,18,19,20$ & 1 \\
& Coves, cliffs and small islands & $8,17,18$ & 0.8 \\
& Sand dunes and beaches & $8,17,18$ & 0.8 \\
& Coastal wetlands & $8,17,18$ & 0.8 \\
& Areas above 900 m & $8,17,18$ & 0.8 \\
Environmental & Lakes, reservoirs, wetlands and their 300-m buffers & $8,17,18$ & 1 \\
assets & Rivers, creeks and their 150-m buffers & $8,17,18$ & 1 \\
& Areas of significant importance for wild animals & $17,18,38,39,40$ & 0.2 \\
& Areas of significant importance for plant species & $17,18,38,39,40$ & 0.2 \\
& Grottos and caves & $8,17,18$ & 0.8 \\
& Monumental trees & $8,17,18$ & 0.2 \\
& Natural monuments (as per regional law 1989/31) & $8,17,18$ & 0.5 \\
& National parks and marine protected areas & $8,17,18$ & 0.5 \\
& Volcanoes & $8,17,18$ & 0.5 \\
\hline
\end{tabular}


Table A4. Cont.

\begin{tabular}{clcc}
\hline & \multicolumn{1}{c}{ Type } & $\begin{array}{c}\text { Plan Implementation } \\
\text { Code: Articles }\end{array}$ & A_Her \\
\hline & Listed buildings and areas (as per art.146 of Decree & 8 & 0.8 \\
& $42 / 2004)$ & 8,47 & 1 \\
Historic and & Listed archaeological heritage & 8,47 & 0.5 \\
cultural assets & Archaeological areas subject to building restrictions & $8,47,48,49,50$ & 1 \\
& Areas with prehistoric, historic, cultural remnants & $8,47,51,52,53$ & 0.8 \\
& Historic districts & $8,47,51,52,54$ & 0.8 \\
\hline
\end{tabular}

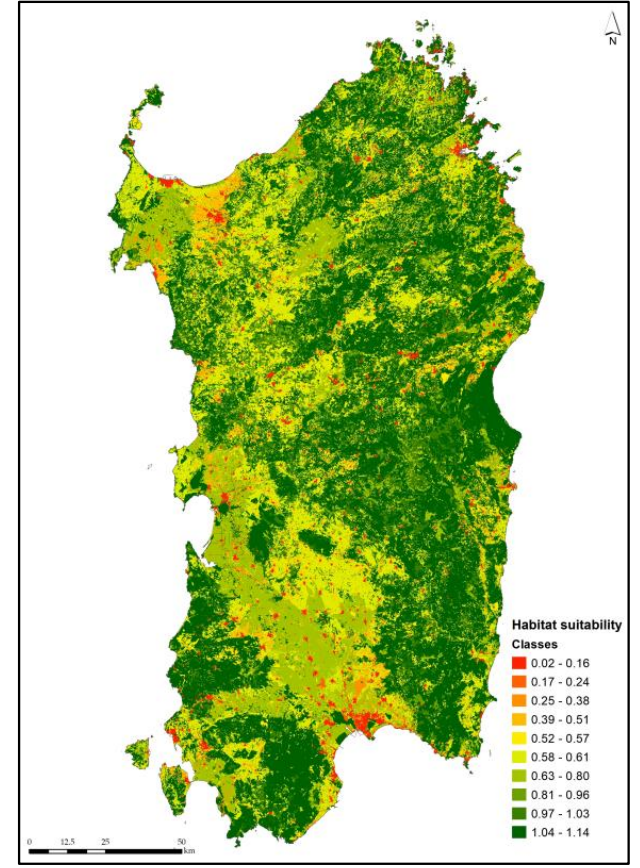

(a)

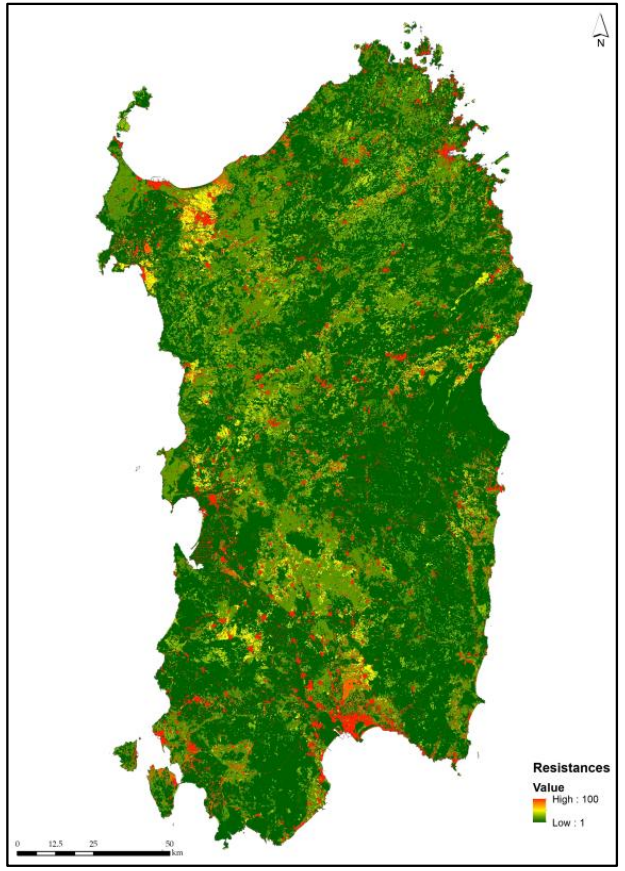

(b)

Figure A1. (a) The habitat suitability map is a vector dataset, at the scale 1:25,000, built through a reclassification of the land cover of Sardinia; $(\mathbf{b})$ the resistance map is a raster dataset, rescaled from 1 to 100 , where the cell size is $25 \mathrm{~m} \times 25 \mathrm{~m}\left(625 \mathrm{~m}^{2}\right)$.

\section{References and Notes}

1. European Commission. Communication from the Commission to the European Parliament, the Council, the Economic and Social Committee and the Committee of the Regions. Green Infrastructure (GI). Enhancing Europe's Natural Capital, 2013. Available online: http://eur-lex.europa.eu/resource.html?uri=cellar: d41348f2-01d5-4abe-b817-4c73e6f1b2df.0014.03/DOC_1\&format=PDF (accessed on 15 March 2018).

2. Liquete, C.; Kleeschulte, S.; Dige, G.; Maes, J.; Grizzetti, B.; Olah, B.; Zulian, G. Mapping Green Infrastructure based on ecosystem services and ecological networks: A pan-European case study. Environ. Sci. Policy 2015, 54, 268-280. [CrossRef]

3. Spanò, M.; Gentile, F.; Davies, C.; Lafortezza, R. The DPSIR Framework in support of green infrastructure planning: A case study in Southern Italy. Land Use Policy 2017, 61, 242-250. [CrossRef]

4. Garmendia, E.; Apostolopoulou, E.; Adams, W.M.; Bormpoudakis, D. Biodiversity and green infrastructure in Europe: Boundary object or ecological trap? Land Use Policy 2016, 56, 315-319. [CrossRef]

5. McHarg, I.L. Design with Nature; Natural History Press: New York, NY, USA, 1969.

6. European Commission. The Multifunctionality of Green Infrastructure. Science for Environment Policy. In-Depth Report, 2012. Available online: http://ec.europa.eu/environment/nature/ecosystems/docs/ Green_Infrastructure.pdf (accessed on 15 March 2018). 
7. Ahern, J. From fail-safe to safe-to-fail. Sustainability and resilience in the new urban world. Landsc. Urban Plan. 2011, 100, 341-343. [CrossRef]

8. Iojă, C.I.; Grădinaru, S.R.; Onose, D.A.; Vânău, G.O.; Tudor, A.C. The potential of school green areas to improve urban green connectivity and multifunctionality. Urban For. Urban Green. 2014, 13, 704-713. [CrossRef]

9. Madureira, H.; Andresen, T. Planning for multifunctional urban green infrastructures: Promises and challenges. Urban Des. Int. 2014, 19, 38-49. [CrossRef]

10. Horwood, K. Green infrastructure: Reconciling urban green space and regional economic development: Lessons learnt from experience in England's north-west region. Local environment. Int. J. Justice Sustain. 2011, 16, 37-41. [CrossRef]

11. Taylor, P.D.; Fahrig, L.; Henein, K.; Merriam, G. Connectivity is a vital element of landscape structure. Oikos 1993, 68, 571-573. [CrossRef]

12. Luque, S.; Saura, S.; Fortin, M.J. Landscape connectivity analysis for conservation: Insights from combining new methods with ecological and genetic data. Landsc. Ecol. 2012, 27, 153-157. [CrossRef]

13. Taylor, P.D.; Fahrig, L.; With, K.A. Landscape Connectivity. A Return to the Basics. In Connectivity Conservation (Conservation Biology Series No. 14); Crooks, K., Sanjayan, M., Eds.; Cambridge University Press: Cambridge, UK, 2006; pp. 29-43. ISBN 9780511754821. [CrossRef]

14. Mühlner, S.; Kormann, U.; Schmidt-Entling, M.H.; Herzog, F.; Bailey, D. Structural versus functional habitat connectivity measures to explain bird diversity in fragmented orchards. J. Landsc. Ecol. 2010, 3, 52-64. [CrossRef]

15. Vogt, P.; Ferrari, J.R.; Lookingbill, T.R.; Gardner, R.H.; Riitters, K.H.; Ostapowicz, K. Mapping functional connectivity. Ecol. Indic. 2009, 9, 64-71. [CrossRef]

16. Pierik, M.E.; Dell'Acqua, M.; Confalonieri, R.; Bocchi, S.; Gomarasca, S. Designing ecological corridors in a fragmented landscape: A fuzzy approach to circuit connectivity analysis. Ecol. Indic. 2016, 67, 807-820. [CrossRef]

17. Pelorosso, R.; Gobattoni, F.; Geri, F.; Monaco, R.; Leone, A. Evaluation of ecosystem services related to Bio-Energy Landscape Connectivity (BELC) for land use decision making across different planning scales. Ecol. Indic. 2016, 61, 114-129. [CrossRef]

18. Snäll, T.; Lehtomäki, J.; Arponen, A.; Elith, J.; Moilanen, A. Green infrastructure design based on spatial conservation prioritization and modelling of biodiversity features and ecosystem services. Environ. Manag. 2016, 57, 251-256. [CrossRef] [PubMed]

19. ISTAT [Italian National Institute of Statistics]. Popolazione Residente al $1^{\circ}$ Gennaio. [Resident Population on January 1st], 2017. Available online: http:/ / dati.istat.it/Index.aspx?DataSetCode=DCIS_POPRES1 (accessed on 15 March 2018).

20. Italian Environmental Ministry. SIC, ZSC e ZPS in Italia [SCIs, SACs, and SPAs in Italy], 2017. Available online: http:/ / www.minambiente.it/pagina/sic-zsc-e-zps-italia (accessed on 15 March 2018).

21. Arcidiacono, A.; Ronchi, S.; Salata, S. Managing multiple ecosystem services for landscape conservation: A green infrastructure in Lombardy region. Procedia Eng. 2016, 161, 2297-2303. [CrossRef]

22. CRITERIA; TEMI. Monitoraggio dello Stato di Conservazione degli Habitat e delle Specie di Importanza Comunitaria Presenti nei Siti della Rete Natura 2000 in Sardegna. Definizione della Rete di Monitoraggio. Volume 2: Piano di Monitoraggio degli Habitat e delle Specie Vegetali [Monitoring the Conservation Status of Habitats and Species of Community Interest within Natura 2000 Sites in Sardinia. Defining a Monitoring System. Volume 2: Monitoring Plan for Habitats and Plant Species]; MIMEO. Unpublished work, 2014.

23. Priority Habitats are defined in the article No. 1 of Habitats Directive as " ... natural habitat types in danger of disappearance, which are present on the territory referred to in article No. 2 and for the conservation of which the Community has particular responsibility in view of the proportion of their natural range which falls within the territory referred to in article No. 2; these priority natural habitat types are marked by an asterisk (*) in Annex I.

24. The Natura 2000 Standard Data Forms provide relevant information for each Natura 2000 site using a format approved under the provisions of EC Decision of 11 July 2011; for each Natura 2000 site, the form can be retrieved through the European Environment Agency's website. Available online: http:/ / natura2000.eea. europa.eu/ (accessed on 15 March 2018). 
25. CRITERIA; TEMI. Monitoraggio dello Stato di Conservazione degli Habitat e delle Specie di Importanza Comunitaria Presenti nei Siti della Rete Natura 2000 in Sardegna. Elaborazione Rapporto di Sintesi sullo Stato di Conservazione di Habitat e Specie (Linea 4, 4.C.1) [Monitoring the Conservation Status of Habitats and Species of Community Interest within Natura 2000 Sites in Sardinia. Synthesis Report on Conservation Status of Habitats and Species (Deliverable 4.c.1)]; MIMEO. Unpublished work, 2014.

26. InVEST (Integrated Valuation of Ecosystem Services and Tradeoffs) Is a free-of-Cost-Software Program Licensed under the BSD Open Source License. As Indicated in the InVEST-Related Documentation. "InVEST Is a Tool for Exploring How Changes in Ecosystems Are Likely to Lead to Changes in Benefits That Flow to People". InVEST Is Developed by the Natural Capital Project, Whose Partners Are: Woods Institute for the Environment and Department of Biology of Stanford University; Institute on the Environment of the University of Minnesota; The Nature Conservancy; and, The World Wildlife Fund (WWF). Available online: http:/ / data.naturalcapitalproject.org/nightly-build/invest-users-guide/html/ (accessed on 15 March 2018).

27. Habitat types are appraised upon the authors' assessment.

28. Millennium Ecosystem Assessment. Ecosystems and Human Well-Being: A Framework for Assessment; Island Press: Washington, DC, USA, 2003; ISBN 1-55963-402-2.

29. Lankia, T.; Kopperoinen, L.; Pouta, E.; Neuvonen, M. Valuing recreational ecosystem service flow in Finland. J. Outdoor Recreat. Tour. 2015, 10, 14-28. [CrossRef]

30. Eagles, P.; McLean, D.; Stabler, M. Estimating the tourism volume and value in protected areas in Canada and the United States. George Wright Forum 2000, 17, 62-76.

31. Sonter, L.J.; Watson, K.B.; Wood, S.A.; Ricketts, T.H. Spatial and temporal dynamics and value of nature-based recreation, estimated via social media. PLoS ONE 2016, 11, 1-16. [CrossRef] [PubMed]

32. Hausmann, A.; Toivonen, T.; Slotow, R.; Tenkanen, H.; Moilanen, A.; Heikinheimo, V.; Di Minin, E. Social media data can be used to understand tourists' preferences for nature-based experiences in protected areas. Conserv. Lett. 2017, 11, 1-10. [CrossRef]

33. Further Information Is. Available online: http:/ / data.naturalcapitalproject.org/nightly-build/invest-usersguide/html/recreation.html (accessed on 15 March 2018).

34. Values are appraised upon the authors' assessment.

35. Adriaensen, F.; Chardon, J.P.; De Blust, G.; Swinnen, E.; Villalba, S.; Gulinck, H.; Matthysen, E. The application of 'least-cost' modelling as a functional landscape model. Landsc. Urban Plan. 2003, 64, 233-247. [CrossRef]

36. Beier, P.; Majka, D.R.; Newell, S.L. Uncertainty analysis of least-cost modeling for designing wildlife linkages. Ecol. Appl. 2009, 19, 2067-2077. [CrossRef] [PubMed]

37. European Environment Agency. Spatial Analysis of Green Infrastructure in Europe; EEA Technical Report 2/2014; Publications Office of the European Union: Luxembourg, 2014; ISBN 978-92-9213-421-1.

38. Lechner, A.M.; Sprod, D.; Carter, O.; Lefroy, E.C. Characterising landscape connectivity for conservation planning using a dispersal guild approach. Landsc. Ecol. 2017, 32, 99-113. [CrossRef]

39. Sawyer, S.C.; Epps, C.W.; Brashares, J.S. Placing linkages among fragmented habitats: Do least-cost models reflect how animals use landscapes? J. Appl. Ecol. 2011, 48, 668-678. [CrossRef]

40. Zeller, K.A.; McGarigal, K.; Whiteley, A.R. Estimating landscape resistance to movement: A review. Landsc. Ecol. 2012, 27, 777-797. [CrossRef]

41. Boitani, L.; Corsi, F.; Falcucci, A.; Maiorano, L.; Marzetti, I.; Masi, M.; Montemaggiori, A.; Ottaviani, D.; Reggiani, G.; Rondinini, C. Rete Ecologica Nazionale. Un Approccio alla Conservazione dei Vertebrati Italiani. Relazione Finale [National Ecological Network. An Approach to Conservation of Italian Vertebrates. Final Report]; Ministero dell'Ambiente e della Tutela del Territorio e Università di Roma La Sapienza: Rome, Italy, 2002.

42. Wang, Y.H.; Yang, K.C.; Bridgman, C.L.; Lin, L.K. Habitat suitability modelling to correlate gene flow with landscape connectivity. Landsc. Ecol. 2008, 23, 989-1000. [CrossRef]

43. Graves, T.; Chandler, R.B.; Royle, J.A.; Beier, P.; Kendall, K.C. Estimating landscape resistance to dispersal. Landsc. Ecol. 2014, 29, 1201-1211. [CrossRef]

44. AGRISTUDIO; CRITERIA; TEMI. Realizzazione del Sistema di Monitoraggio dello Stato di Conservazione degli Habitat e delle Specie di Interesse Comunitario della Regione Autonoma della Sardegna. Relazione Generale, Allegato 1b: Carta dell'Idoneità Faunistica [Implementation of the Monitoring System Concerning the Conservation Status of Habitats and Species of Community Interest of the Autonomous Region of Sardinia. General Report, Attachment 1b: Habitat Suitability Map]; MIMEO. Unpublished work, 2011. 
45. Land Cover Class Are Classed According to the CORINE Land Cover Taxonomy. The Nomenclature Is Available on the European Environment Agency's Website. Available online: https: / www.eea.europa.eu/ publications / COR0-landcover (accessed on 15 March 2018).

46. Forman, R.T.T. Land Mosaics. The Ecology of Landscapes and Regions; Cambridge University Press: Cambridge, UK, 1995; ISBN 9780521479806.

47. Linkage Mapper Is a GIS Tool That Analyzes Habitat Connectivity. Available online: http://www. circuitscape.org/linkagemapper (accessed on 15 March 2018).

48. McFadden, D. Modelling the Choice of Residential Location. In Spatial Interaction Theory and Planning Models; Karlqvist, A., Lundqvist, L., Snickars, F., Weibull, J.V., Eds.; North Holland: Amsterdam, The Netherlands, 1978; pp. 75-96, ISBN-10 0444851828.

49. McFadden, D. Econometric models for probabilistic choice among products. J. Bus. 1980, 53, 13-29. [CrossRef]

50. Williams, H.C.W.L. On the formation of travel demand models and economic evaluation measures of user benefit. Environ. Plan. A 1977, 9, 285-344. [CrossRef]

51. McFadden, D. Disaggregate Behavioural Travel Demand's RUM Side. A 30-Year Retrospective. In Travel Behavior Research: The Leading Edge; Hensher, D., Ed.; Pergamon Press: Oxford, UK, 2000; pp. 17-63, ISBN-10 008043360X.

52. Train, K. Discrete Choice Methods with Simulation; Cambridge University Press: Cambridge, UK, 2009.

53. De Dios Ortúzar, J.; Willumsen, L.G. Modelling Transport, 3rd ed.; John Wiley: Hoboken, NJ, USA, 2001; ISBN-10 0471861103.

54. Ben-Akiva, M.; Lerman, S. Discrete Choice Analysis: Theory and Application to Travel Demand (Transportation Studies); The MIT Press: Cambridge, MA, USA, 1985; ISBN 9780262332576.

55. Tversky, A. Elimination by aspects: A theory of choice. Psychol. Rev. 1972, 79, 281-299. [CrossRef]

56. Zoppi, C.; Lai, S. Differentials in the regional operational program expenditure for public services and infrastructure in the coastal cities of Sardinia (Italy) analyzed in the ruling context of the regional landscape plan. Land Use Policy 2013, 30, 286-304. [CrossRef]

57. Nerlove, M.; Press, S. Univariate and Multivariate Log-Linear and Logistic Models, Report No. R1306-EDA/NIH; RAND Corporation: Santa Monica, CA, USA, 1973.

58. Greene, W.H. Econometric Analysis; Macmillan: New York, NY, USA, 1993; ISBN-10-0-273-75356-8.

59. McRae, B.H.; Kavanagh, D.M. Linkage Mapper Connectivity Analysis Software; The Nature Conservancy: Seattle, WA, USA, 2011; Available online: http:/ / www.circuitscape.org/linkagemapper (accessed on 15 March 2018).

60. Hosmer, D.W.; Lemeshow, S. Applied Logistic Regression; John Wiley \& Sons: New York, NY, USA, 1989; ISBN 978-0471356325.

61. Meerow, S.; Newell, J.P. Spatial planning for multifunctional green infrastructure: Growing resilience in Detroit. Landsc. Urban Plan. 2017, 159, 62-75. [CrossRef]

62. Council of Europe. European Landscape Convention. (CETS No. 176), 2000. Available online: https: / /rm.coe.int/1680080621 (accessed on 15 March 2018).

63. Lovell, S.T.; Taylor, J.R. Supplying urban ecosystem services through multifunctional green infrastructure in the United States. Landsc. Ecol. 2013, 28, 1447-1493. [CrossRef]

64. Landsberg, F.; Ozment, S.; Stickler, M.; Henninger, N.; Treweek, J.; Venn, O.; Mock, G. Ecosystem Services Review for Impact Assessment: Introduction and Guide to Scoping, WRI Working Paper; World Resources Institute: Washington, DC, USA, 2011.

65. Kovács, E.; Kelemen, K.; Kalóczkai, A.; Margóczi, K.; Pataki, G.; Gébert, J.; Málovics, G.; Balázs, B.; Roboz, A.; Krasznai Kovács, E.; Mihók, B. Understanding the links between ecosystem service trade-offs and conflicts in protected areas. Ecosyst. Serv. 2015, 12, 117-127. [CrossRef]

(C) 2018 by the authors. Licensee MDPI, Basel, Switzerland. This article is an open access article distributed under the terms and conditions of the Creative Commons Attribution (CC BY) license (http:/ / creativecommons.org/licenses/by/4.0/). 